\title{
LIMIT STATE OF ARCHES OF VARIABLE STIFFNESS
}

\author{
Soroka M.M., PhD, Associate Professor, \\ soroka@ogasa.org.ua, ORCID: 0000-0002-9551-9475 \\ Odessa State Academy of Civil Engineering and Architecture \\ st. Didrikhson, 4, Odessa,65029, Ukraine
}

\begin{abstract}
An algorithm is proposed for numerically solving the problem of finding the maximum load for flat bar systems having a rectangular section of variable height. The material is elastoplastic; its physical properties are described by the Prandtl diagram. It is assumed that the compressive $\sigma_{y t}$ and tensile $\sigma_{y t}$ strength of the material are different. The modulus of elasticity in tension and compression is the same. The limiting state of a rectangular cross section under the simultaneous action of a longitudinal force and a bending moment is described. Using the proposed algorithm, a program was developed for calculating rod systems by the limit equilibrium.

The $\mathrm{C}++$ programming language was used to create a program for the numerical determination of the ultimate load for rod systems. The finite element method was used as the most universal to write a module that performs static analysis of the bar system. Its use makes it easy to design rod systems of arbitrary configuration with arbitrary boundary conditions.

As a test example, a hinged circular arch loaded with a uniformly distributed vertical load is considered. Analytical dependences are written, which allow to obtain the ultimate load for an arch of variable section. Examples of calculating the limiting state of the arch and comparing the ultimate loads with and without longitudinal force are considered. The analytical solution is compared with the numerical solution found by the author's program. Good convergence of analytical and numerical solutions is shown.

The proposed algorithm for the numerical calculation of the limit states uses the so-called direct method for finding the ultimate load. This allows not only to obtain the value of the ultimate load, but also to establish the order of formation of plastic regions in the sections of the rod system. The calculation algorithm does not imply the use of iterative processes, which has a positive effect on the speed of calculations. Within the accepted assumptions, the calculation methodology is accurate.
\end{abstract}

Keywords: ultimate load, material properties, longitudinal force accounting, hinge-free arch, numerical solution, calculation program.

Introduction. The theory of calculation of allowable stresses is widely used in the calculations of the supporting structures of buildings and structures under the action of specified loads. This allows you to design reliable structures that have some margin of safety. However, the calculation method for allowable stresses does not allow to identify the margin of safety and determine the maximum load that the structure can withstand. In [1-4], fundamental theorems were proved and a method of calculating by limiting equilibrium was substantiated, which allows finding the ultimate load for various structures. The method is based on the use of the hypothesis of ideal elastic plasticity of the material and analysis of the limiting state of the structure. The ultimate equilibrium method allows revealing latent safety margins and designing more economical structures. Using this method allows you to get analytical dependencies to find the ultimate load for arch systems.

Analysis of recent research. When calculating bar systems using the equilibrium method, as a rule, only bending moments are taken into account. The influence of longitudinal and transverse forces is considered insignificant. For frame structures, this is true, but for arch systems, neglect of longitudinal forces leads to large errors. Modern arched structures, in most cases, have variable stiffness in order to reduce material consumption. The materials from which arches are built do not always have equal tensile and compression strengths, for example, concrete, wood, and some composites. The calculation of the ultimate load for structures made of similar materials requires the creation of an appropriate design apparatus. The methods available in the literature for 
calculating the ultimate load for arches [5-7] do not take into account the presence of different tensile strengths of the material under compression and tension.

The purpose of paper. In this paper, we solve the problem of numerically finding the ultimate load for flat bar systems using the method of ultimate equilibrium. It is assumed that the rods have a rectangular cross section of variable stiffness and are made of a material with different tensile and compressive strengths. As an example, considered a circular hinge-free arch. In the literature known to the author, it was not possible to find studies devoted to calculating the limiting state of arches of variable cross section with different tensile and compression strengths. Therefore, in this paper, we propose a method for the numerical and analytical calculation of such arches using the method of limiting equilibrium. The numerical calculation technique is implemented as a calculation program.

Materials and methods. For the numerical determination of the ultimate load, the direct method is used, which was used in [4] to calculate rod systems without taking into account the longitudinal force. A similar method was used by the author in $[8,9]$ to calculate the ultimate load while taking into account the longitudinal force and bending moment for bar systems with elements of constant stiffness. In this paper, the algorithm [9] is slightly modified and adapted to calculate systems with elements of variable stiffness. The analytical determination of the ultimate load for the arch is based on the solution of the linear programming problem [3] with the use of yield conditions.

Research results. To calculate the rod systems by the method of limiting equilibrium, it is necessary to describe the limiting state of the cross section under the action of longitudinal force and bending moment.

Considering the limiting state of a rectangular section, the height of which depends on its coordinate $a$, we use results, obtained in [9] for rectangle section with constant height. With the simultaneous action of a longitudinal force and a bending moment, the section strength region is described by the dependences:

- under compressive longitudinal force:

$$
\left|\frac{M_{b}(\alpha)}{M_{0}(\alpha)}\right|+\left(\frac{N_{b}(\alpha)}{N_{0 c}(\alpha)}\right)^{2} \cdot \frac{\sigma_{y c}}{\sigma_{y t}}-\frac{N_{b}(\alpha)}{N_{0 c}(\alpha)} \cdot \frac{\sigma_{y c}-\sigma_{y t}}{\sigma_{y t}}=1 ;
$$

- under the action of tensile longitudinal force:

$$
\left|\frac{M_{b}(\alpha)}{M_{0}(\alpha)}\right|+\left(\frac{N_{b}(\alpha)}{N_{0 t}(\alpha)}\right)^{2} \cdot \frac{\sigma_{y t}}{\sigma_{y c}}+\frac{N_{b}(\alpha)}{N_{0 t}(\alpha)} \cdot \frac{\sigma_{y c}-\sigma_{y t}}{\sigma_{y c}}=1,
$$

where $\alpha$-section coordinate; $\sigma_{y c}$ - compressive strength; $\sigma_{y t}$ - tensile strength; $M_{0}(\alpha)$ ultimate moment of section in the absence of longitudinal force.

$$
M_{0}(\alpha)=\frac{b h^{2}(\alpha)}{2} \frac{\sigma_{y c} \sigma_{y t}}{\sigma_{y c}+\sigma_{y t}},
$$

$b, h(\alpha)$ - section width and height;

$N_{0 c}(\alpha), N_{0 t}(\alpha)$ - ultimate compressive and tensile forces in the absence of moment;

$$
N_{0 c}(\alpha)=-\sigma_{y c} b h(\alpha) ; N_{0 t}(\alpha)=\sigma_{y t} b h(\alpha),
$$

$M_{b}(\alpha), N_{b}(\alpha)$ - limit values of moment and longitudinal force with simultaneous action of both longitudinal force and moment. $M_{b}(\alpha)$ and $N_{b}(\alpha)$ are on the border of the cross-section strength region [8].

Expressions (1) and (2), which are called yield conditions, allow us to write and solve the problem of finding the ultimate load for flat bar systems with a rectangular cross section.

For the numerical solution of the problem of limit equilibrium, the finite element method was used. The core system was divided into finite elements of constant stiffness and the yield conditions (1), or (2) were used to calculate the ultimate forces in each section. 
The idea of the calculation is that while the forces $M(\alpha)$ and $N(\alpha)$ fall inside the strength region, the cross section is in the elastic stage and the relationship between the load and the forces is linear [8]. On the first stage of calculation, having forces $M_{1}(\alpha) N_{1}(\alpha)$ from the action of a unit load, it is easy to calculate the ultimate forces $M_{b}(\alpha), N_{b}(\alpha)$ and the ultimate load at which the cross section passes into the plastic stage. After calculating such a load for each design section, we select the section for which the load will be minimal. In this section, we install the hinge and take the axial stiffness equal to zero, that is, remove two bonds. We calculate the values of the forces in all calculated sections from the obtained ultimate load. If the system has not turned into a mechanism, the calculation continues. At the second stage, taking into account the efforts found at the first stage, we calculate the load increment, which transfers the next section of the core system to the plastic stage. The calculation stops when the system turns into a mechanism. The ultimate load will be the sum of the loads found at all stages of the calculation. The calculation procedure is quite simple and allows you to trace all the stages of the gradual transformation of the core system into a mechanism.

Ultimate forces for the section are defined as the intersection point of force vector $M(\alpha)$, $N(\alpha)$ with the border of strength region [8]. Thus, ultimate forces $M_{b}(\alpha)$ and $N_{b}(\alpha)$ are calculated from the solutions of the system of two equations.

a) At compressed section:

$$
\begin{gathered}
M_{b}(\alpha)-M_{s}(\alpha)-k_{1}(\alpha)\left[N_{b}(\alpha)-N_{s}(\alpha)\right]=0 ; \\
\left|\frac{M_{b}(\alpha)}{M_{0}(\alpha)}\right|+\left[\frac{N_{b}(\alpha)}{N_{0 c}(\alpha)}\right]^{2} \cdot \frac{\sigma_{y c}}{\sigma_{y t}}-\frac{N_{b}(\alpha)}{N_{0 c}(\alpha)} \cdot \frac{\sigma_{y c}-\sigma_{y t}}{\sigma_{y t}}-1=0,
\end{gathered}
$$

where $M_{s}(\alpha)$ and $N_{s}(\alpha)$ - forces in section, obtained on the previous stage of calculation (on the first stage these forces are equal to zero);

$k_{1}(\alpha)=M_{1}(\alpha) / N_{1}(\alpha)$, where $M_{1}(\alpha)$ and $N_{1}(\alpha)$ - forces in section of unit load.

Ultimate compressive force is determined from the expression:

$$
\begin{aligned}
& \frac{N_{b}(\alpha)}{N_{0 c}(\alpha)}=\frac{1}{2}-\frac{\sigma_{y t}}{2 \sigma_{y c}}\left[1+k_{1}(\alpha) k_{c}(\alpha)\right]+ \\
& +\sqrt{\left\{\frac{1}{2}-\frac{\sigma_{y t}}{2 \sigma_{y c}}\left[1+k_{1}(\alpha) k_{c}(\alpha)\right]\right\}^{2}+\frac{\sigma_{y t}}{M_{0}(\alpha) \sigma_{y c}}\left[k_{1}(\alpha) N_{s}(\alpha)-M_{s}(\alpha)+M_{0}(\alpha)\right]},
\end{aligned}
$$

where $k_{c}(\alpha)=N_{0 c}(\alpha) / M_{0}(\alpha)$.

b) At stretched section:

$$
\begin{aligned}
& M_{b}(\alpha)-M_{s}(\alpha)-k_{1}(\alpha)\left[N_{b}(\alpha)-N_{s}(\alpha)\right]=0 \\
& \left|\frac{M_{b}(\alpha)}{M_{0}(\alpha)}\right|+\left[\frac{N_{b}(\alpha)}{N_{0 t}(\alpha)}\right]^{2} \cdot \frac{\sigma_{y t}}{\sigma_{y c}}-\frac{N_{b}(\alpha)}{N_{0 t}(\alpha)} \cdot \frac{\sigma_{y c}-\sigma_{y t}}{\sigma_{y c}}-1=0 .
\end{aligned}
$$

The ultimate tensile force is determined from the expression:

$$
\frac{\frac{N_{b}(\alpha)}{N_{0 t}(\alpha)}=\frac{1}{2}-\frac{\sigma_{y c}}{2 \sigma_{y t}}\left[1+k_{1}(\alpha) k_{t}(\alpha)\right]+}{+\sqrt{\left\{\frac{1}{2}-\frac{\sigma_{y c}}{2 \sigma_{y t}}\left[1-k_{1}(\alpha) k_{t}(\alpha)\right]\right\}^{2}+\frac{\sigma_{y c}}{M_{0}(\alpha) \sigma_{y t}}\left[k_{1}(\alpha) N_{s}(\alpha)-M_{s}(\alpha)+M_{0}(\alpha)\right]},}
$$

where $k_{t}(\alpha)=N_{0 t}(\alpha) / M_{0}(\alpha)$.

The described calculation procedure is implemented as a calculation program in the $\mathrm{C}++$ programming language. Since the finite element method was used, the program allows one to perform the calculation according to the method of limiting equilibrium for arbitrary flat rod systems. 
To test the program, we write an analytical solution to the problem of finding the maximum load for a hinge-free arch.

Example 1.

Let us consider a circular hinge-free arch of variable section loaded with a uniformly distributed load (Fig. 1, a). We assume that the moment of inertia of the cross section of the arch changes according to the law:

$$
I(\alpha)=\frac{I_{C}}{\sin \alpha},
$$

where $I_{C}$ - moment of inertia of the section located on the axis of symmetry of the arch.

With a rectangular cross section, the height of the section will be determined by the formula:

$$
h(\alpha)=\frac{h_{C}}{\sqrt[3]{\sin \alpha}},
$$

where $h_{C}-$ section height on the axis of symmetry of the arch.

Arch's cross-section area:

$$
A(\alpha)=\frac{A_{C}}{\sqrt[3]{\sin \alpha}} \approx \frac{A_{C}}{\sin \alpha},
$$

where $A_{C}=b h_{C}$ - cross-sectional area on the axis of symmetry of the arch.

Static arch calculation is performed using the force method using the center of elastic weight (Fig. 1, b). The coordinate of the center of elastic weight is determined by the formula:

$$
y_{0}=\frac{R}{4 \cos \alpha_{0}}\left(\pi-2 \alpha_{0}+\sin \alpha_{0}\right) .
$$

Unknown of the force methods are determined from the system of equations:

$$
\left\{\begin{array}{l}
\delta_{11} X_{1}+\Delta_{1 q}=0 \\
\delta_{22} X_{2}+\Delta_{2 q}=0
\end{array}\right.
$$

Forces in the main system of the method of forces from single unknowns $X_{1}, X_{2}$ and of the given load $q$ :

$$
\begin{aligned}
& \bar{M}_{1}=y_{0}-R \sin \alpha ; \bar{N}_{1}=-\sin \alpha ; \\
& \bar{M}_{2}=-1 ; \bar{N}_{2}=0 ; \\
& M_{q}^{0}=-\frac{q R^{2}}{2} \cos ^{2} \alpha ; N_{q}^{0}=-q R \cos ^{2} \alpha .
\end{aligned}
$$

\section{a)}

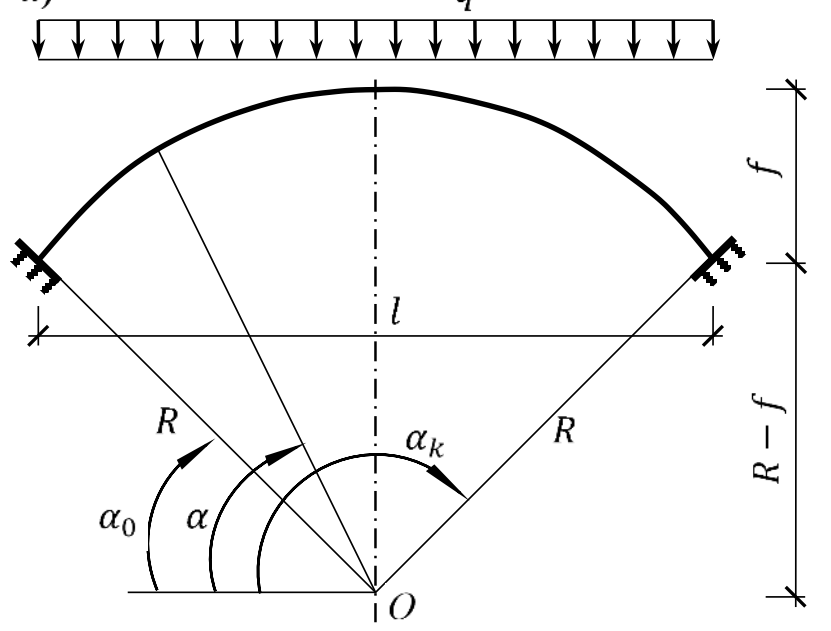

b)

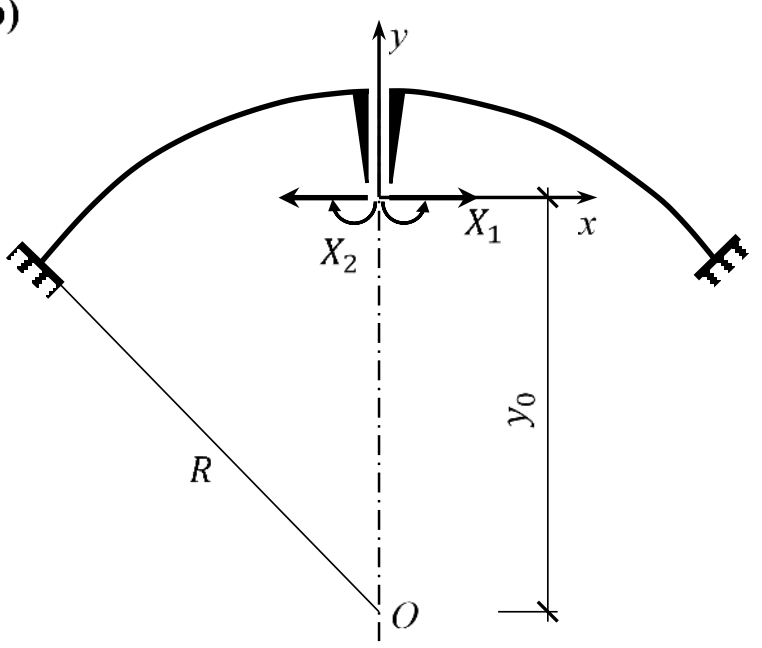

Fig. 1. Calculation model of the arch and main system of force method 
The coefficients of the system of equations:

$$
\begin{gathered}
\delta_{11}=\int_{\alpha_{0}}^{\alpha_{k}} \frac{\bar{M}_{1}^{2}}{E I(\alpha)} R d \alpha+\int_{\alpha_{0}}^{\alpha_{k}} \frac{\bar{N}_{1}^{2}}{E A(\alpha)} R d \alpha= \\
=\left\{\left[y_{0}^{2}+R^{2}\left(1-\frac{1}{3} \cos ^{2} \alpha_{0}\right)\right] \cos \alpha_{0}-R y_{0}\left(\frac{\pi}{2}-\alpha_{0}+\frac{1}{2} \sin 2 \alpha_{0}\right)\right\}+\frac{2 R}{E A_{C}}\left(1-\frac{1}{3} \cos ^{2} \alpha_{0}\right) \cos \alpha_{0} ; \\
\delta_{22}=\int_{\alpha_{0}}^{\alpha_{k}} \frac{\bar{M}_{2}^{2}}{E I(\alpha)} R d \alpha+\int_{\alpha_{0}}^{\alpha_{k}} \frac{\bar{N}_{2}^{2}}{E A(\alpha)} R d \alpha=\frac{2 R}{E I_{C}} \cos \alpha_{0} ; \\
\Delta_{1 q}=\int_{\alpha_{0}}^{\alpha_{k}} \frac{\bar{M}_{1} M_{q}^{0}}{E I(\alpha)} R d \alpha+\int_{\alpha_{0}}^{\alpha_{k}} \frac{\bar{N}_{1} N_{q}^{0}}{E A(\alpha)} R d \alpha=\frac{q R^{3}}{E I_{C}}\left[\frac{y_{0}}{3} \cos ^{3} \alpha_{0}-\frac{R}{8}\left(\frac{\pi}{2}-\alpha_{0}+\frac{1}{4} \sin 4 \alpha_{0}\right)\right]+ \\
\Delta_{2 q}=\int_{\alpha_{0}}^{\alpha_{k}} \frac{\bar{M}_{2} M_{q}^{0}}{E I(\alpha)} R d \alpha+\int_{\alpha_{0}}^{\alpha_{k}} \frac{\bar{N}_{2} N_{q}^{0}}{E A(\alpha)} R d \alpha=\frac{q R^{3}}{3 E I_{C}} \cos ^{3} \alpha_{0} .
\end{gathered}
$$

From the solution of the system of equations (13) we find unknown forces:

$$
H=X_{1}=-\frac{\Delta_{1 q}}{\delta_{11}} ; M_{C}=X_{2}=-\frac{\Delta_{2 q}}{\delta_{22}} .
$$

We write down the expressions for the moment and longitudinal force in an arbitrary section of the arch:

$$
\begin{gathered}
M(\alpha)=-\frac{q R^{2}}{2} \cos ^{2} \alpha+H\left(y_{0}-R \sin \alpha\right)-M_{C} \\
N(\alpha)=-q R \cos ^{2} \alpha-H \sin \alpha .
\end{gathered}
$$

Having expressions for efforts (17) and plasticity conditions (1), (2), we can formulate the optimization problem, where the ultimate function is the ultimate load $q_{0}$, and the project variable will be the coordinate of the section $\alpha$, which will go into a plastic state. Since under the action of a given load all sections of the arch are compressed, condition (1) is used as a plasticity condition. Values $H$ and $M_{C}$ are determined by (16):

$$
\left\{\begin{array}{l}
q_{0} \rightarrow \text { min } \\
M_{b}(\alpha)=-\frac{q_{0} R^{2}}{2} \cos ^{2} \alpha+H\left(y_{0}-R \sin \alpha\right)-M_{C} ; \\
N_{b}(\alpha)=-q_{0} R \cos ^{2} \alpha-H \sin \alpha ; \\
\left|\frac{M_{b}(\alpha)}{M_{0}(\alpha)}\right|+\left[\frac{N_{b}(\alpha)}{N_{0 c}(\alpha)}\right]^{2} \cdot \frac{\sigma_{y c}}{\sigma_{y t}}-\frac{N_{b}(\alpha)}{N_{0 c}(\alpha)} \cdot \frac{\sigma_{y c}-\sigma_{y t}}{\sigma_{y t}}=1 .
\end{array}\right.
$$

In view of symmetry $\alpha_{0} \leq \alpha \leq \pi / 2$.

As a numerical example, consider an arch with parameters: $l=20 \mathrm{~m}, f=8 \mathrm{~m}, R=10.25 \mathrm{~m}, \alpha_{0}=0.22131 \mathrm{rad}, \alpha_{k}=2.92028 \mathrm{rad} . \quad$ Transverse section $b \times h_{C}=0.2 \times 0.4 m^{2}$. Material properties $\quad E=2.3 \cdot 10^{7} \mathrm{kN} / \mathrm{m}^{2}, \quad \sigma_{y c}=14500 \mathrm{kN} / \mathrm{m}^{2}$, $\sigma_{y t}=1000 \mathrm{kN} / \mathrm{m}^{2}$.

Problem (18) was solved in EXCEL using the "Solution Search" function. The following results are obtained: $\quad q_{0}=6.7656 \mathrm{kN} / \mathrm{m}, \quad \alpha=0.22131 \mathrm{rad}, \quad M_{b}(\alpha)=62.3055 \mathrm{kNm}$, $N_{b}=-76.6001 k N$. Plastic arises in two supporting sections of the arch. Since the transition of one 
section into a plastic state removes two bonds, the arch turns into a mechanism.

Diagrams of moments and longitudinal forces in the ultimate state are presented in Fig. 2.

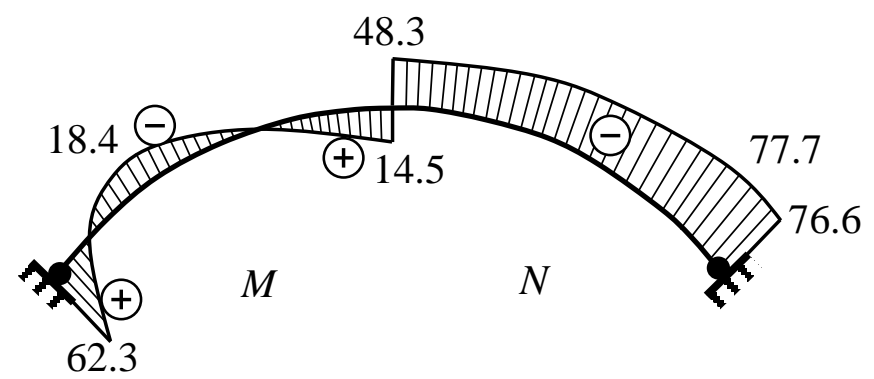

Fig. 2. Diagrams of forces in the ultimate state of the arch

\section{Example 2.}

Consider the hinge-free arch shown in Fig. 1a. If the longitudinal force is not taken into account when calculating the ultimate load for the arch, then, taking into account symmetry, the formation of five plastic joints is necessary for turning the arch into a mechanism. Two plastic hinges are formed in the supporting sections of the arch, the third on the axis of symmetry of the arch. To determine the ultimate load and sections in which two more hinges are formed, we write the system of equations:

$$
\left\{\begin{array}{l}
H=\left[0.125 q_{0} l^{2}+M_{0}\left(\alpha_{0}\right)-M_{0}(\pi / 2)\right] / f \\
\frac{q_{0} l^{2}}{8}-\frac{q_{0} R^{2}}{2} \cos ^{2} \alpha-H(R \sin \alpha-R+f)+M_{0}\left(\alpha_{0}\right)+M_{0}(\alpha)=0 \\
\pm\left(q_{0} R^{2} \sin \alpha-H R\right)^{3} \sin ^{5}(\alpha)-M_{0}^{3}(\pi / 2) / 3.375=0 .
\end{array}\right.
$$

Having solved the system of equations (19) for the arch with the parameters specified in example 1, we obtain: $q_{0}=5.81088 \mathrm{kN} / \mathrm{m}, \alpha=0.76795 \mathrm{rad}$. Plastic hinges are formed symmetrically at a distance of $2.627 \mathrm{~m}$ from the arch supports. The resulting ultimate load is $16 \%$ less than the ultimate load obtained in Example 1. This indicates that the presence of compressive longitudinal force and allowance for its influence in the equations of ultimate equilibrium leads to an increase in ultimate load.

The numerical calculation of the arch from Example 1 leads to the following results: ultimate load is $6.779 \mathrm{kN} / \mathrm{m}$, the supporting sections of the arch go into the plastic state. This result was obtained by dividing the axis of the arch into 132 finite elements. The obtained ultimate load differs from that obtained analytically by $0.2 \%$.

Having performed the numerical calculation of the arch from example 2, we obtain $q_{0}=5.8180 \mathrm{kN} / \mathrm{m}$, which differs from the analytical calculation by $0.1 \%$. The first two plastic hinges are formed in the supporting sections of the arch, the next two are symmetrically at a distance of $2.75 \mathrm{~m}$ from the supports, the last is a plastic hinge on the axis of symmetry of the arch.

It should be noted that in the numerical calculation the coincidence of the maximum load with the load obtained analytically, in the general case, depends on the degree of fragmentation of the arch into finite elements. But a good agreement of the results can also be achieved with a small partition if the nodes of the finite element model fall into the sections, where plastic is formed in the analytical calculation.

\section{Conclusion:}

1. The direct method of calculating the limit equilibrium $[4,9]$ makes it easy to develop an algorithm for the numerical calculation of bar systems of variable stiffness and implement it in the form of program code. 
2. The numerical calculation method allows you to establish the sequence of transition of the sections into a plastic state.

3. Calculations showed good convergence of analytical and numerical results.

4. The presence of compressive longitudinal force and its consideration in solving problems of ultimate equilibrium leads to an increase in ultimate load in arch systems.

\title{
References
}

[1] A.A. Gvozdev, Raschet nesuschej sposobnosti konstrykcij po metody predelnogo ravnovesiya. Moscow: Stroyizdat, 1949.

[2] A.R. Rzhanitsyn, Raschet soorygenij s ychetom plasticheskih svoistv materialov. Moscow: Gostehizdat, 1954.

[3] A.A. Chiras, Stroitelnaya mekhanika, teorija i algoritmi. Moscow: Stroyizdat, 1989.

[4] A.V. Darkov, N.N. Shaposhnikov, Stroitelnaya mechanika. Moscow: "Vysshaya shkola", 1986.

[5] R.F. Gabbasov, Chan Tkhan Tung, "Chislennyj metod rascheta arok po predelnomu ravnovesiyu", Vestnik MGSU, no. 4, vol. 1, pp. 18-23. 2010.

[6] Chan Tkhan Tung, "Chislennij method rascheta arok po predelnomy ravnovesiu", Vestnik $M G S U$, no. 1, t. 1, pp. 232-237, 2011.

[7] N.I. Popov, O predelnom sostoyanii arki, nagrygenoj sistemoj sosredotochennih sil. Trudy RIIZhT, issue 29, 1961.

[8] Mykola Soroka, The limit state of non-hinged arch with a cross-section in the form of an idealized I-beam. [Online]. Available: http://www.enggjournals.com/ijet/vol10issue6.html Accessed on: September 21, 2020.

[9] Mykola Soroka, "Bearing capacity of structures made of materials with different tensile and compression strengths", Actual Problems of Engineering Mechanics, 6th International Conference, vol. 968, pp. 200-208, 2019.

\section{ГРАНИЧНИЙ СТАН АРОК ЗМІННОЇ ЖОРСТКОСТІ}

\author{
Сорока М.М., к.т.н., професор, \\ soroka@ogasa.org.ua, ORCID: 0000-0002-9551-9475 \\ Одеська державна академія будівництва та архітектури \\ вул. Дідріхсона, 4, м. Одеса, 65029, Україна
}

Анотація. Запропоновано алгоритм чисельного рішення задачі знаходження граничного навантаження для плоских стрижневих систем, що мають прямокутний перетин змінної висоти. Матеріал - пружно-пластичний, його фізичні властивості описуються діаграмою Прандтля. Передбачається, що межі міцності матеріалу при стисненні і при розтягуванні різні. Модуль пружності при розтягуванні і стисненні однаковий. Описано граничний стан прямокутного перетину при одночасній дії поздовжньої сили і згинального моменту. 3 використанням запропонованого алгоритму складена програма розрахунку стрижневих систем за методом граничної рівноваги.

Для створення програми чисельного визначення граничного навантаження для стрижневих систем використовувався мова програмування $\mathrm{C}++$. Для написання модуля, що виконує статичний розрахунок стрижневої системи, як найбільш універсальний, використовувався метод скінчених елементів. Його використання дозволяє легко розраховувати стрижневі системи довільної конфігурації з довільними граничними умовами.

В якості тестового прикладу розглянута безшарнірна кругова арка, завантажена вертикальним рівномірно-розподіленим навантаженням. Записані аналітичні залежності, що дозволяють отримати граничне навантаження для арки змінного перерізу. Розглянуто приклади розрахунку граничного стану арки i порівняння граничних навантажень 3 
урахуванням і без урахування поздовжньої сили. Виконано порівняння аналітичного рішення 3 чисельним рішенням, знайденим за програмою автора. Показана хороша збіжність аналітичного і чисельного рішень.

У запропонованому алгоритмі чисельного розрахунку за граничними станами використовується так званий прямий метод знаходження граничного навантаження. Це дозволяє не тільки отримати значення граничного навантаження, але і встановити порядок утворення пластичних областей в перетинах стрижневої системи. Алгоритм розрахунку не передбачає використання ітераційних процесів, що позитивно позначається на швидкості обчислень. У межах прийнятих припущень методика розрахунку є точною.

Ключові слова: граничне навантаження, властивості матеріалу, облік поздовжньої сили, безшарнірних арка, чисельне рішення, програма розрахунку.

\title{
ПРЕДЕЛЬНОЕ СОСТОЯНИЕ АРОК ПЕРЕМЕННОЙ ЖЕСТКОСТИ
}

\author{
Сорока Н.Н., к.т.Н., профессор, \\ soroka@ogasa.org.ua, ORCID: 0000-0002-9551-9475 \\ Одесская государственная академия строительства и архитектурь \\ ул. Дидрихсона, 4, г. Одесса, 65029, Украина
}

Аннотация. Предложен алгоритм численного решения задачи нахождения предельной нагрузки для плоских стержневых систем, имеющих прямоугольное сечение переменной высоты. Материал - упругопластический, его физические свойства описываются диаграммой Прандтля. Предполагается, что пределы прочности материала при сжатии $\sigma_{y c}$ и при растяжении $\sigma_{y t}$ разные $\left(\sigma_{y c}>\sigma_{y t}\right)$. Модуль упругости при растяжении и сжатии одинаков. Описано предельное состояние прямоугольного сечения при одновременном действии продольной силы и изгибающего момента. С использованием предложенного алгоритма составлена программа расчета стержневых систем по предельному равновесию.

Для создания программы численного определения предельной нагрузки для стержневых систем использовался язык программирования $\mathrm{C}++$. Для написания модуля, выполняющего статический расчет стержневой системы, как наиболее универсальный, использовался метод конечных элементов. Его использование позволяет легко рассчитывать стержневые системы произвольной конфигурации с произвольными граничными условиями.

В качестве тестового примера рассмотрена бесшарнирная круговая арка, загруженная вертикальной равномерно-распределенной нагрузкой. Записаны аналитические зависимости, позволяющие получить предельную нагрузку для арки переменного сечения. Рассмотрены примеры расчета предельного состояния арки и сравнение предельных нагрузок с учетом и без учета продольной силы. Выполнено сравнение аналитического решения с численным решением, найденным по программе автора. Показана хорошая сходимость аналитического и численного решений.

В предложенном алгоритме численного расчета по предельным состояниям используется так называемый прямой метод нахождения предельной нагрузки. Это позволяет не только получить значение предельной нагрузки, но и установить порядок образования пластических областей в сечениях стержневой системы. Алгоритм расчета не предполагает использования итерационных процессов, что положительно сказывается на скорости вычислений. В пределах принятых допущений методика расчета является точной.

Ключевые слова: предельная нагрузка, свойства материала, учет продольной силы, бесшарнирная арка, численное решение, программа расчета.

Стаття надійшла до редакції 23.10.2020 